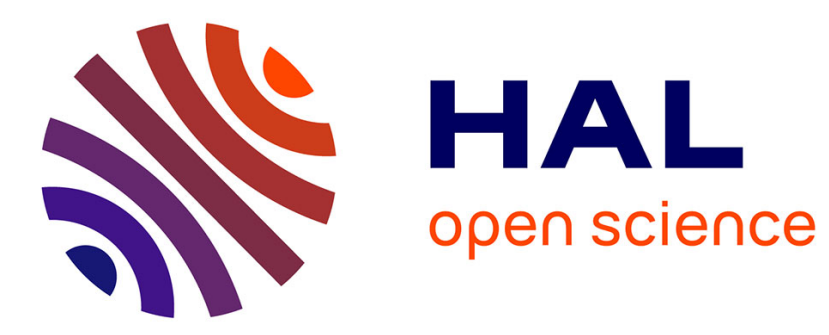

\title{
HIGH-TC-SUPERCONDUCTORS PREPARED BY CVD
}

\author{
F. Schmaderer, R. Huber, H. Oetzmann, G. Wahl
}

\section{To cite this version:}

F. Schmaderer, R. Huber, H. Oetzmann, G. Wahl. HIGH-TC-SUPERCONDUCTORS PREPARED BY CVD. Journal de Physique IV Proceedings, 1991, 02 (C2), pp.C2-539-C2-548. 10.1051/jp4:1991264 . jpa-00249854

\section{HAL Id: jpa-00249854 https://hal.science/jpa-00249854}

Submitted on 1 Jan 1991

HAL is a multi-disciplinary open access archive for the deposit and dissemination of scientific research documents, whether they are published or not. The documents may come from teaching and research institutions in France or abroad, or from public or private research centers.
L'archive ouverte pluridisciplinaire HAL, est destinée au dépôt et à la diffusion de documents scientifiques de niveau recherche, publiés ou non, émanant des établissements d'enseignement et de recherche français ou étrangers, des laboratoires publics ou privés. 
Colloque C2, suppl. au Journal de Physique II, Vol. 1, septembre 1991

\title{
HIGH-TC-SUPERCONDUCTORS PREPARED BY CVD
}

\author{
F. SCHMADERER ${ }^{*}$, R. HUBER ${ }^{*}, H$. OETZMANN ${ }^{*}$ and G. WAHL * \\ *Asea Brown Boveri AG, Corporate Research Heidelberg, \\ P.O. Box 1013 32, D-6900 Heidelberg 1, Germany \\ ** Technical University. Inst. f. Surface Technology. \\ Braunschweig, Germany
}

\begin{abstract}
:
$\mathrm{YBa}_{2} \mathrm{Cu}_{3} \mathrm{O}_{7-\delta}$ - deposition experiments were carried out in a cold wall stagnation flow CVD-reactor on single crystalline (100)-oriented $\mathrm{SrTiO}_{3}$-substrates at a total pressure of 10 mbar. As source materials different $\beta$-diketonate derivates of yttrium, barium and copper were investigated concerning their volatility and decomposition behaviour. Finally for the $\mathrm{YBa}_{2} \mathrm{Cu}_{3} \mathrm{O}_{7-\delta}$ deposition process $\mathrm{Y}(\text { thd })_{3}, \mathrm{Ba}$ (thd $)_{2}$ and $\mathrm{Cu}(\text { thd })_{2}$ were used. The evaporation temperatures $T_{v}$ were 112,208 and $117^{\circ} \mathrm{C}$ respectively. High quality films can be obtained with the c-axis perdendicular to the substrate surface at temperatures higher than $850^{\circ} \mathrm{C}$. The transition temperatures of the coatings are higher than $90 \mathrm{~K}$ and the critical current densities are in the order of $j_{c}=10^{6} \mathrm{~A} / \mathrm{cm}^{2}$ at $77 \mathrm{~K}$ and self magnetic field.
\end{abstract}

\section{Introduction:}

Suitable production methods of High-Tc-superconducting thin films for electronic (e.g. SQUID's, microwave-devices, integrated circuits) and electrotechnical (e.g. cables, magnets, current limiters, transformers, storage devices) applications in the most cases require the deposition on large areas. The deposited films should be uniform in thickness and composition and the growth rates should satisfy industrial demands. For electrotechnical applications normally thick superconducting layers $\left(d_{s}>1 \mu \mathrm{m}\right)$ are necessary in order to obtain a large superconducting cross-section leading to a high current carrying ability. This means that, due to the anisotropic properties of the oxide superconductors, epitaxial grain growth with layers thicker than $1 \mu \mathrm{m}$ are required. Chemical vapour deposition satisfies this requirement due to the molecular nature of the deposition process. Furthermore, it is well known, that in the case of complicated shaped substrate geometries (e.g. fibres), CVD seems to be the only technique, compared to all physical vapour deposition techniques and wet chemical procedures, to realize these demands. Meanwhile these potential of CVD has been recognized by an increasing number of scientists at the universities as well as in the industrial laboratories $/ 1 /$. However, the main problem in the development of the CVD-process for High$\mathrm{T}_{\mathrm{c}}$-superconductors till now is the availability of suitable source materials with acceptable physical and chemical properties. 
This paper describes investigations on possible source materials concerning their usability for the CVD-process of $\mathrm{YBa}_{2} \mathrm{Cu}_{3} \mathrm{O}_{7-\delta}$ deposition. The CVD-equipment which has been used for the deposition process, the deposition kinetics and the superconducting properties of the $\mathrm{YBa}_{2} \mathrm{Cu}_{3} \mathrm{O}_{7-8}$ coatings are described.

\section{Source materials:}

Each CVD-process requires suitable precursors carrying the elements, which have to be deposited via the vapour phase onto the hot substrate material. The demands on such precursors are manyfold. They should have to be thermally stable and have high vapour pressures at moderate temperatures up to $300^{\circ} \mathrm{C}$ but they should decompose at temperatures higher than $500^{\circ} \mathrm{C}$ without the formation of stable residuals during their pyrolysis. The precursors currently used for the deposition of High-Tc-superconductors in the YBaCuO-system are mainly B-diketonate derivates which are well known to form volatile metal-compounds $/ 2 / 3 /$. Only a few results are known concerning the application of halides $14 \%$. Tab. 1 summarizes some possible ß-diketonates of yttrium, barium and copper.

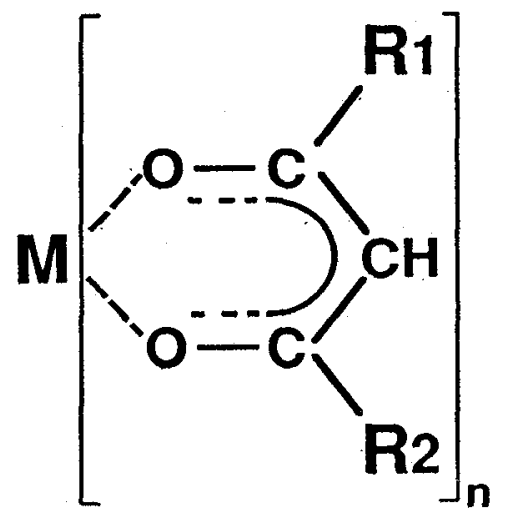

\begin{tabular}{|c|c|c|}
\hline R1 & R2 & Short $\mathrm{Na}$ \\
\hline $\mathrm{CH}_{3}$ & $\mathrm{CH}_{3}$ & $M(a c a c)_{n}$ \\
\hline $\mathrm{t}-\mathrm{C}_{4} \mathrm{H}_{9}$ & $t-\mathrm{C}_{4} \mathrm{H}_{9}$ & $\begin{array}{l}M(\text { thd })_{n} \\
M(d p m)_{n}\end{array}$ \\
\hline $\mathrm{CF}_{3}$ & $\mathrm{CF}_{3}$ & $M(h f a c) n$ \\
\hline$n-C_{3} F_{7}$ & $\mathrm{t}-\mathrm{C}_{4} \mathrm{H}_{9}$ & $M(\text { fod })_{n}$ \\
\hline
\end{tabular}

Table 1: Source materials, with: acac: acetylacetone or 2.4-pentanedione; hfac = hexafluoroacetylacetone or 1.1.1.5.5.5-hexafluoropentane-2.4-dione; thd $=2.2 .6 .6$-tetramethylheptane-3.5-dione or $\mathrm{dpm}=$ dipivaloylmethane and fod $=1$ 1.1.1.2.2.3.3-heptafluoro7.7-dimethyloctane-4.6-dione.

The results of evaporation experiments in the CVD-arrangement /5/6/ are shown in fig. 1, where the molar evaporation rates $\dot{n}_{e v}$ of the investigated compounds are plotted in a logarithmic scale versus the reciporcal evaporation temperature $T_{v}$. The experiments were carried out at a total pressure of $p_{\text {tot }}=10 \mathrm{mbar}$ and a carrier gas flow of $50 \mathrm{l} / \mathrm{h}$ Argon (STP). The geometry of the evaporation crucibles is described in more detail in $17 /$. The evaporation rates $n_{e v}$ were determined by measuring the weight change of the powder after the experiments. 


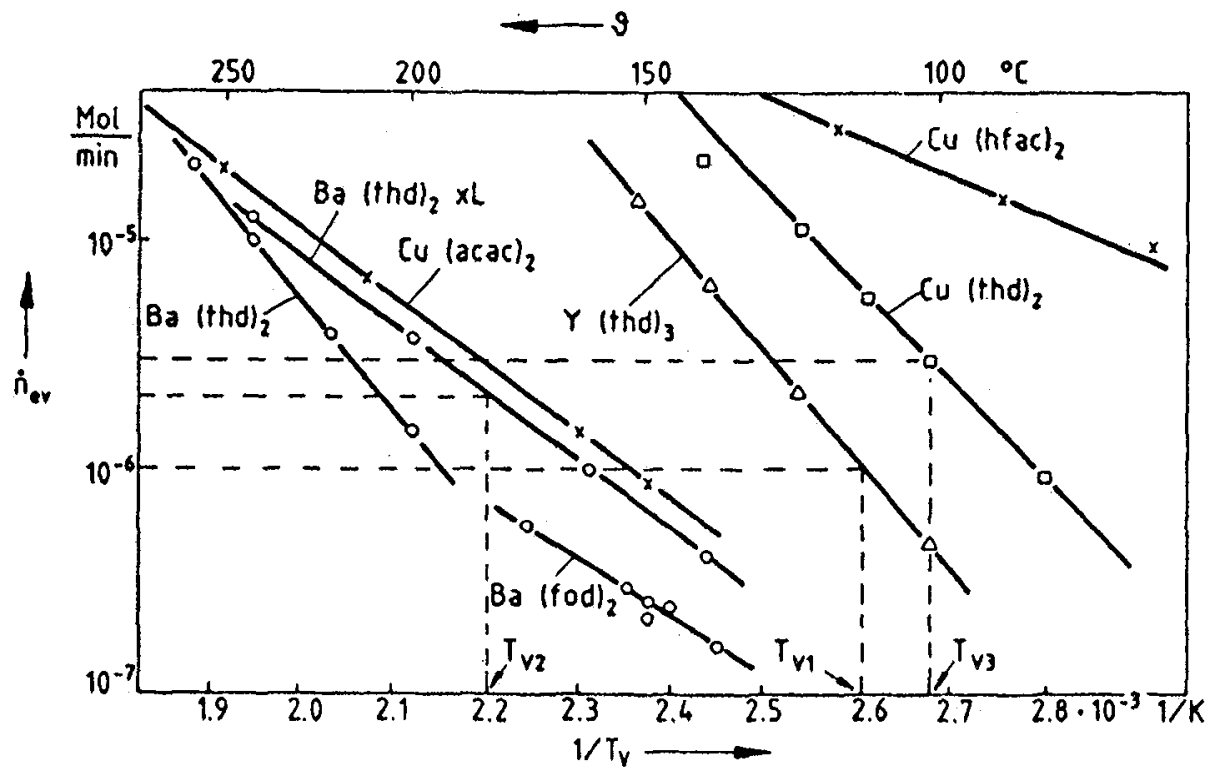

Fig. 1: Molar evaporation rates $\dot{n}_{\mathrm{ev}}$ of $\mathrm{Y}(\text { thd })_{3}, \mathrm{Ba}$ (thd $)_{2}$ with and without $H($ thd $), \mathrm{Ba}(\mathrm{fod})_{2}$, $\mathrm{Cu}(\mathrm{acac})_{2}, \mathrm{Cu}(\text { thd })_{2}$ and $\mathrm{Cu}(\mathrm{hfac})_{2}$ versus the reciprocal evaporation temperature $T_{v}$.

In the case of copper we have investigated $\mathrm{Cu}(\mathrm{acac})_{2}, \mathrm{Cu}(\mathrm{hfac})_{2}$ and $\mathrm{Cu}(\text { thd })_{3}$. The evaporation behaviour of these compounds is very different. The volatility increases in the sequence $\mathrm{Cu}(\mathrm{acac})_{2}<\mathrm{Cu}(\text { thd })_{2}<\mathrm{Cu}(\mathrm{hfac})_{2}$ mainly caused by the different ligands, which influence the van-der-Waal's interactions between adjacent molecules. Pyrolysis of these compounds in oxygen containing atmosphere at temperatures $\mathrm{T}>500^{\circ} \mathrm{C}$ leads in every case to monoclinic CuO /5/. In the case of Yttrium only $Y(\text { thd })_{3}$ has been investigated. The evaporation behaviour is very similar to that observed with $\mathrm{Cu}(\text { thd })_{2}$ but shifted to higher temperatures. Thermal decomposition leads to stoichiometric $\mathrm{Y}_{2} \mathrm{O}_{3} / 5 /$. In the case of Barium precursors three compounds have been investigated: $\mathrm{Ba}(\mathrm{acac})_{2}, \mathrm{Ba}(\mathrm{fod})_{2}$ and $\mathrm{Ba}$ (thd $)_{2} . \mathrm{Ba}(\mathrm{acac})_{2}$ is not usable for a CVD-process because it already dissociates in the crucible and only the volatile organic parts of the molecules leave the evaporator. Ba(fod) 2 shows a rather good volatility at temperatures below $200^{\circ} \mathrm{C}$. The main disadvantage of this compound is, that it decomposes on the hot substrate to $\mathrm{BaF}_{2}$ which is thermodynamically exceptionally stable $/ 8 /$ and can only be converted to the corresponding oxide by an additional heat treatment in a water-containing atmosphere $19 \% \mathrm{Ba}$ (thd) 2 has the advantage of flourine free decomposition products (BaO with small amounts of $\left.\mathrm{BaCO}_{3}\right) / 5 /$ although high temperatures $\left(\mathrm{T}_{v}>200^{\circ} \mathrm{C}\right)$ are necessary in order to obtain suitable evaporation rates ( $\left.\dot{n}_{e v}>10^{-6} \mathrm{~mol} / \mathrm{min}\right)$. The disadvantage of this compound, compared to the yttrium- and copper-chelates, is, however, a strong tendency to form oligomers during the evaporation process. The reason for this behaviour is the unsaturated coordination sphere of Barium. The Cu(II)-ion in $\mathrm{Cu}(\mathrm{acac})_{2} / 10 / 11 /$ as well as in $\mathrm{Cu}(\mathrm{thd})_{2} / 12 /$ is surrounded by four oxygen atoms forming a planar square. Yttrium is surrounded by six oxygen atoms forming an octahedral coordination sphere as electron diffaction investigations in the vapour phase by S. Shibata et al. $/ 13 /$ have shown. Therefore the Cu-chelates as well as $Y(\text { thd })_{3}$ are expected to exist as monomeric molecules. However, the coordination sphere of the barium ion is unsaturated by the four oxygen atoms of the two chelate ligands. Higher coordination numbers can be attained by adding solvents or by oligomerization $/ 14 /$. This behaviour of $\mathrm{Ba}$ (thd $)_{2}$ compared to $\mathrm{Y}(\text { thd })_{3}$ and $\mathrm{Cu}$ (thd $)_{2}$ was clearly observed doing evaporation experiments in a microbalance. The set-up of the arrangement is described in $17 /$. The evaporation conditions in the microblance were similar to those in the CVD-equipment. 
Only the geometry of the crucible was different. As carrier gas we used $\mathrm{Ar}+\mathrm{O}_{2}(1: 1)$ at a total pressure of 10 mbar. All compounds showed some instabilities during the heating-up period (30 $\mathrm{min})$ due to the additional evaporation of residuals of water, solvents or free ligands. After this heating-up period the evaporation of $\mathrm{Y}(\mathrm{thd})_{3}$ and $\mathrm{Cu}(\mathrm{thd})_{2}$ became stable within the investigated period of time $(10 \mathrm{~h})$. Ba(thd $)_{2}$, however, showed constant evaporation rates only if the evaporation temperature was in the range of $200^{\circ} \mathrm{C}$ or below (depending on the supplier). At higher temperatures $\left(200^{\circ} \mathrm{C}<\mathrm{T}_{v}<250^{\circ} \mathrm{C}\right)$ the decrease of the evaporation rates of $\mathrm{Ba}$ (thd) 2 with time becomes more significant 171 . AAS-analysis (atomic absorption spectroscopy) of the $\mathrm{Ba}$ (thd)2-precursor before and after the experiment at $\mathrm{T}_{\mathrm{v}}=220^{\circ} \mathrm{C}$ showed an increase of the Ba-content from $26.3 \pm 0,03 \%$ in the initial material (theoretical value is $27,25 \%$ ) to $35,7 \%$ in the residual substance. This indicates, that the main reason for the gradual decrease of the evaporation rates of $\mathrm{Ba}$ (thd) 2 must be partly decomposition or the strong interaction between the molecules, due to the unsaturated coordination sphere of $\mathrm{Ba}$, which leads to an oligomerization to higher units. This effect significantly increases with increasing temperature. To overcome this some groups have tried to add donor ligands occupying free coordination sites. We have found $/ 5 / 7 /$, as was also proposed by P.H. Dickinson et al. $115 /$, that adding $H$ (thd) (2.2.6.6-tetramethyl-3.5-heptanedionate) to the carrier gas, the transport rates of $\mathrm{Ba}(\mathrm{thd}) 2$ can be stabilized with time at temperatures $\mathrm{T}_{v}<220^{\circ} \mathrm{C}$, and in addition, the temperature dependence of the evaporation rate decreases (fig. 1, $\mathrm{Ba}$ (thd) $2 \times \mathrm{L}$ )), corresponding to a lower activation energy. Other possiblilities have been shown by S. Matsumo et al. /16/ adding THF (tetrahydrofuran) and recently by C.F. Barron /17/ who added nitrogen containing gases such as ammonia or amines (e.g. NEt3) to Ba- $\beta-$ diketonates instead of an oxygen donor, resulting in a depression of the melting point of $\mathrm{Ba}$ (thd $)_{2}\left(70-100^{\circ} \mathrm{C}\right)$ and constant vapour pressures. The TNO group $/ 18 /$ synthesized $\mathrm{Ba}$ (hfac)2.tetraglyme [Barium bis (1.1.1.5.5.5.-hexafluoropentane-2.4-dionate) 2.5.8.11.14pentaoxapentadecane)], a fluorinated complex which is air-stable and exhibits a high stability of evaporation rate even after prolonged time. However, decomposition experiments with this complex under usual CVD-conditions also resulted in the formation of $\mathrm{BaF}_{2} / 19 /$. For example the preparation of the $\mathrm{HT}_{\mathrm{C}}$-supercondutor $\mathrm{Bi}-\mathrm{Sr}-\mathrm{Ca}-\mathrm{Cu}-\mathrm{O}$ by J.M. Zhang et al. $/ 20 /$ using these fluorinated compounds also resulted in films with fluoride phases showing semiconducting behaviour in a first step before posttreating the films in an oxygen-containing atmosphere at $650^{\circ} \mathrm{C}$ and $865^{\circ} \mathrm{C}$. To avoid the problems caused by the (thd)-system Th. Kruck and coworkers $/ 21 /$ proposed the use of real organometallic precursors such as ( $\eta^{8}$-cyclooctatetraenyl) ( $\eta^{5}$-cyclopentadienyl) yttrium $\left((\mathrm{COT})\left(\mathrm{C} p^{*}\right) \mathrm{Y}\right)$, bis ( $\eta^{5}$-pentamethylcyclopentadienyl) barium $\left(\mathrm{Cp}_{2}{ }_{2} \mathrm{Ba}\right)$ and $\left(\eta^{5}\right.$-cyclopentadienyl)-(triethylphosphine) copper (Cp(PEt 3$\left.) \mathrm{Cu}\right)$, which should have similar evaporation temperatures (below $200^{\circ} \mathrm{C}$ ) with no formation of associates. However, no results concerning the evaporation behaviour of these compounds and their decomposition kinetics are available till now.

For our $\mathrm{YBa}_{2} \mathrm{Cu}_{3} \mathrm{O}_{7-\delta}$ deposition experiments we chose $\mathrm{Y}(\text { thd })_{3}, \mathrm{Ba}$ (thd) $)_{2}$ and $\mathrm{Cu}$ (thd) $)_{2}$ as source materials due to their similar evaporation behaviour and moreover in order to avoid fluoride formation in the coating.

\section{Desposition experiments:}

Fig. 2 shows a schematic diagram of the CVD arrangement used for the deposition experiments of $\mathrm{YBa}_{2} \mathrm{Cu}_{3} \mathrm{O}_{7-8}$ on flat substrates. The equipment mainly consists of three parts: the gas supply, the evaporators and the reactor. The evaporators, made from stainless steel, are electrically heated independently from each other due to the different evaporation behaviour of the source materials in order to control the stoichiometry of the coatings. The evaporation temperatures $\mathrm{T}_{v}$ are measured directly in the powder by a NiCr/Ni thermocouple. The temperatures $T_{v 1.2 .3}$ which are neccessary for a 1:2:3 stoichiometry of $Y(\text { thd })_{3}, B a(t h d)_{2}$ and $\mathrm{Cu}(\text { thd })_{2}$ in the vapour phase are, as an example indicated in fig. 1 . Like in most cases $/ 1 /$ the 
gaseous evaporated compounds are transported with the help of a carrier gas $(18 \mathrm{l} / \mathrm{h}$ oxygen (STP) for each evaporator and in addition $40 \mathrm{l} / \mathrm{h}$ argon (STP) which was enriched with $\mathrm{H}$ (thd) by bubbling through the co-evaporator for $\mathrm{Ba}(\text { thd })_{2}$ ) into the CVD-reactor. Only few results are known concerning the evaporation of the source materials without carrier gas $/ 22 / 23 /$ or by introducing the solid precursors directly into the CVD-reactor e.g. With the help of a powder feeder $/ 24 /$. The vertical reactor $(\$ 50 \mathrm{~mm}$ ) is a cold-wall type with a stagnation flow arrangement. The substrate holder, made by an Ni-based alloy (Nimonic), is heated inductively using an RFGenerator $(200 \mathrm{KHz}, 2,5 \mathrm{~kW})$. The temperature $T_{s}$ of the substrate holder is measured by a $\mathrm{NiCr} / \mathrm{Ni}$ - thermocouple inserted into the substrate holder on the backside of the sample. The temperature of the substrate surface is approximately $100^{\circ} \mathrm{C}$ lower at $T_{s}=950^{\circ} \mathrm{C}$. To exclude the instability of the evaporation behaviour of the source materials during the heating-up period and in order to obtain defined deposition times, we have installed a thermostated by-pass line made from stainless steel, with two heated valves which allows to separate the gas flow from the CVD-reactor during the initial phase. The stagnation flow reactor, which has already been described in detail $/ 5 / 25 / 26$ / has the advantages, that reactions between the reactor wall and reactive species can be minimized and that a very homogeneous mass transport to the substrate surface can be obtained if suitable flow conditions are used.

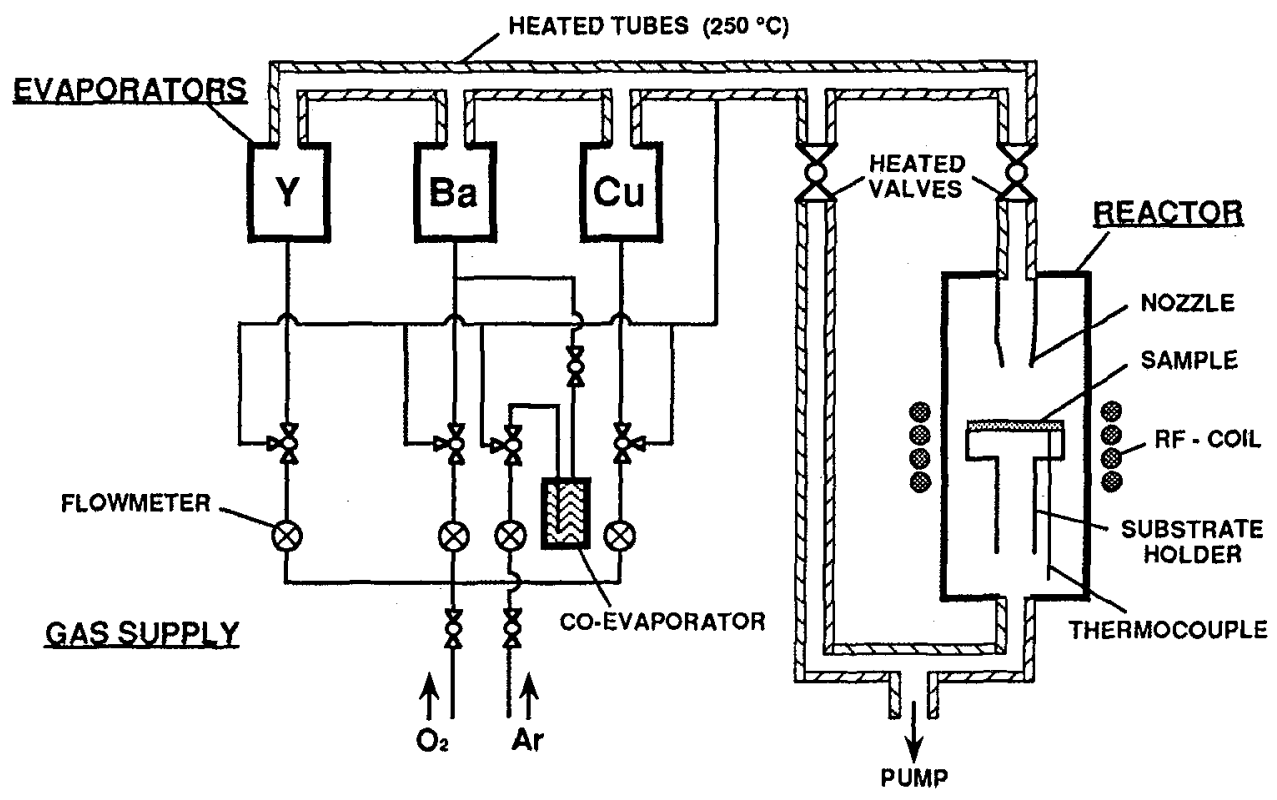

Fig. 2: Schematic diagram of the CVD-arrangement

All deposition experiments were carried out at a total pressure of $p_{t o t}=10 \mathrm{mbar}$. Typical deposition times were between 30-60 min. After the deposition experiment the reactor was filled up with pure oxygen to ambient pressure within $10 \mathrm{~min}$ and cooled down to room temperature with a cooling rate of $15^{\circ} \mathrm{C} / \mathrm{min}$. As substrate material single crystalline (100)-oriented $\mathrm{SrTiO}_{3}$ $\left(1 \mathrm{~cm}^{2}\right)$ was used due to its good lattice matching with the $a-b$-plane of $Y \mathrm{Ba}_{2} \mathrm{Cu}_{3} \mathrm{O}_{7-\delta}$ providing the deposition of highly oriented layers.

Fig. 3 shows in a logarithmic scale the growth rates $\dot{s}$ of $\mathrm{YBa}_{2} \mathrm{Cu}_{3} \mathrm{O}_{7.8}$ versus the reciprocal substrate holder temperature $\mathrm{T}_{\mathrm{s}}$. This curve is typical for a CVD-process. At low temperatures $\left(\mathrm{T}_{\mathrm{S}}<600^{\circ} \mathrm{C}\right)$ the deposition of $\mathrm{YBa}_{2} \mathrm{Cu}_{3} \mathrm{O}_{7-\delta}$ is temperature dependent with an activation 
energy of $E_{A}=82 \mathrm{~kJ} / \mathrm{mol}$. In this region the deposition is controlled by the kinetics of the thermal decomposition of the source materials on the hot substrate surface forming $\mathrm{YBa}_{2} \mathrm{Cu}_{3} \mathrm{O}_{7-\delta}$. This deposition range therefore should be favoured if complicated shaped deposition geometries have to be coated homogeneously. However, at these low temperatures $\left(T_{s}<600^{\circ} \mathrm{C}\right.$ ) the surface mobility of adsorbed molecules is low and the supersaturation of the gas phase is high. Both leads to a high nucleation rate but low crystal growth rate and therefore to a fine-grained structure with poor superconducting properties. At temperatures higher than $\mathrm{T}_{s}=600^{\circ} \mathrm{C}$ the deposition rates of $\mathrm{YBa}_{2} \mathrm{Cu}_{3} \mathrm{O}_{7-\delta}$ become indepedent of the substrate temperature $T_{S}$. In this region the deposition rates are limited by the mass transport of reactive spezies towards the substrate surface /27/. Maximum deposition rates obtained, under the conditions mentioned above, were $20 \mathrm{~nm} / \mathrm{min}$. These, however, can be increased by increasing the evaporation rates of the source materials. Depositions in the mass transport controlled range has the advantage that the deposition rates are high and moreover that the surface mobility increases with increasing temperature $T_{s}$. This provides, together with a low supersaturation suitable conditions for highly textured or even epitaxial coatings.

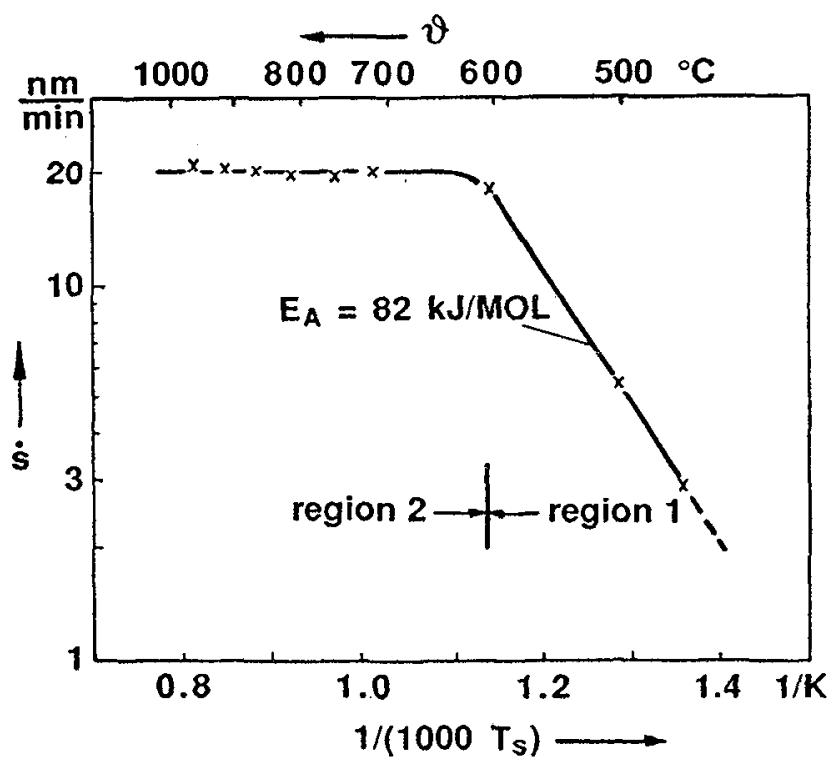

Fig. 3 : Growth rates $\dot{s}$ of $\mathrm{YBa}_{2} \mathrm{Cu}_{3} \mathrm{O}_{7-\delta}$ versus the reciprocal abs. deposition temperature $T_{s}$

The composition of the coatings has been measured with the help of EDX-analysis within a rectangular area of $45 \times 100 \mu \mathrm{m}$, by comparison (linear extrapolation) with a stoichiometric $\mathrm{YBa}_{2} \mathrm{Cu}_{3} \mathrm{O}_{7-\delta}$ standard. We have found, that in the mass transport controlled deposition range the composition of the coatings only slightly deviates from the composition of the vapour phase. However, in the temperature dependent deposition range the composition of the layer strongly deviates from the composition of the vapour phase. The deviations increase with decreasing temperature $T_{s}$. This effect can be explained by the different decomposition kinetics of the source materials $/ 5 / 25 /$ as shown in fig. 4 , where the normalized deposition rates of the single oxides are plotted versus the reciprocal deposition temperature $T_{s}$. It can be seen, that the thermal decomposition of $Y(\text { thd })_{3}$ to $\mathrm{Y}_{2} \mathrm{O}_{3}$ is strongly temperature dependent at $\mathrm{T}_{\mathrm{S}}<480^{\circ} \mathrm{C}$ with an activation energy of $\mathrm{E}_{\mathrm{A}}=120 \mathrm{~kJ} / \mathrm{mol}$. The decomposition of $\mathrm{Cu}(\mathrm{thd})_{2}$ is 
temperature dependent at temperature $T_{S}<530^{\circ} \mathrm{C}$ with $E_{A}=35 \mathrm{~kJ} / \mathrm{mol}$. The $\mathrm{Ba}$ (thd) 2 decomposition, leading to a mixture of $\mathrm{BaO}$ and $\mathrm{BaCO}_{3}$, is kinetically controlled at $\mathrm{T}<800^{\circ} \mathrm{C}$ with an activation energy $\left(E_{A}=73 \mathrm{~kJ} / \mathrm{mol}\right)$ which is similar to the activation energy found for the simultaneous deposition of $\mathrm{YBa}_{2} \mathrm{Cu}_{3} \mathrm{O}_{7-\delta}$, but shifted to higher temperatures.

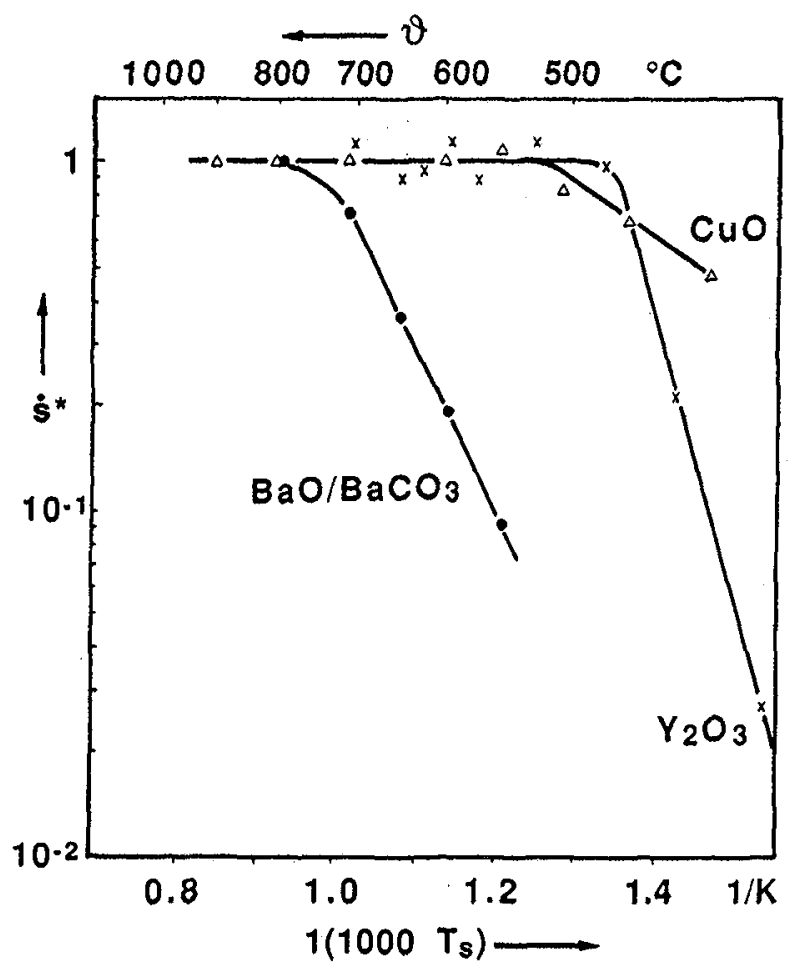

Fig. 4: Normalized deposition rates $\dot{s}$ of the single oxides $\mathrm{Y}_{2} \mathrm{O}_{3}, \mathrm{BaO} / \mathrm{BaCO}_{3}$ and $\mathrm{CuO}$ versus the reciprocal absolute deposition temperature $T_{S}$

\section{Results:}

Fig. 5a shows a typical SEM-image of the surface morphology of $\mathrm{YBa}_{2} \mathrm{Cu}_{3} \mathrm{O}_{7-\delta}$ which has been deposited on single crystalline (100)-oriented $\mathrm{SrTiO}_{3}$ substrates at $\mathrm{T}_{S}=950^{\circ} \mathrm{C}$. EDXanalysis shows that the coating consist of a dense smooth $\mathrm{YBa}_{2} \mathrm{Cu}_{3} \mathrm{O}_{7-8}$-matrix into which $\mathrm{Ba}$ free precipitates are inserted. These copper-yttrium-oxides are already formed during the initial growth process. The cross-section in fig. $5 \mathrm{~b}$ clarifies that the precipitates range from the original substrate surface through the $\mathrm{YBa}_{2} \mathrm{Cu}_{3} \mathrm{O}_{7-\delta}$-matrix to the top of the layer. This precipitates are mainly caused by instabilities in the vapour phase due to the strong temperature dependence of the evaporation process of the source materials (a deviation of $1{ }^{\circ} \mathrm{C}$ results in a change of $10 \%$ of the evaporation rate, fig. 1) and by the changing quality of the source materials from run to run. The deviation of the overall composition of the layer from the stoichiometry of the $\mathrm{YBa}_{2} \mathrm{Cu}_{3} \mathrm{O}_{7-\delta}$-phase can be characterized by a number $\varepsilon$, which is defined by the ratio of the number $N_{p}$ of metal atoms in the precipitates and the total number $N_{t}$ of metal atoms in the layer. $N_{t}$ was calculated from the measured overall composition and $N_{p}$ by comparison 

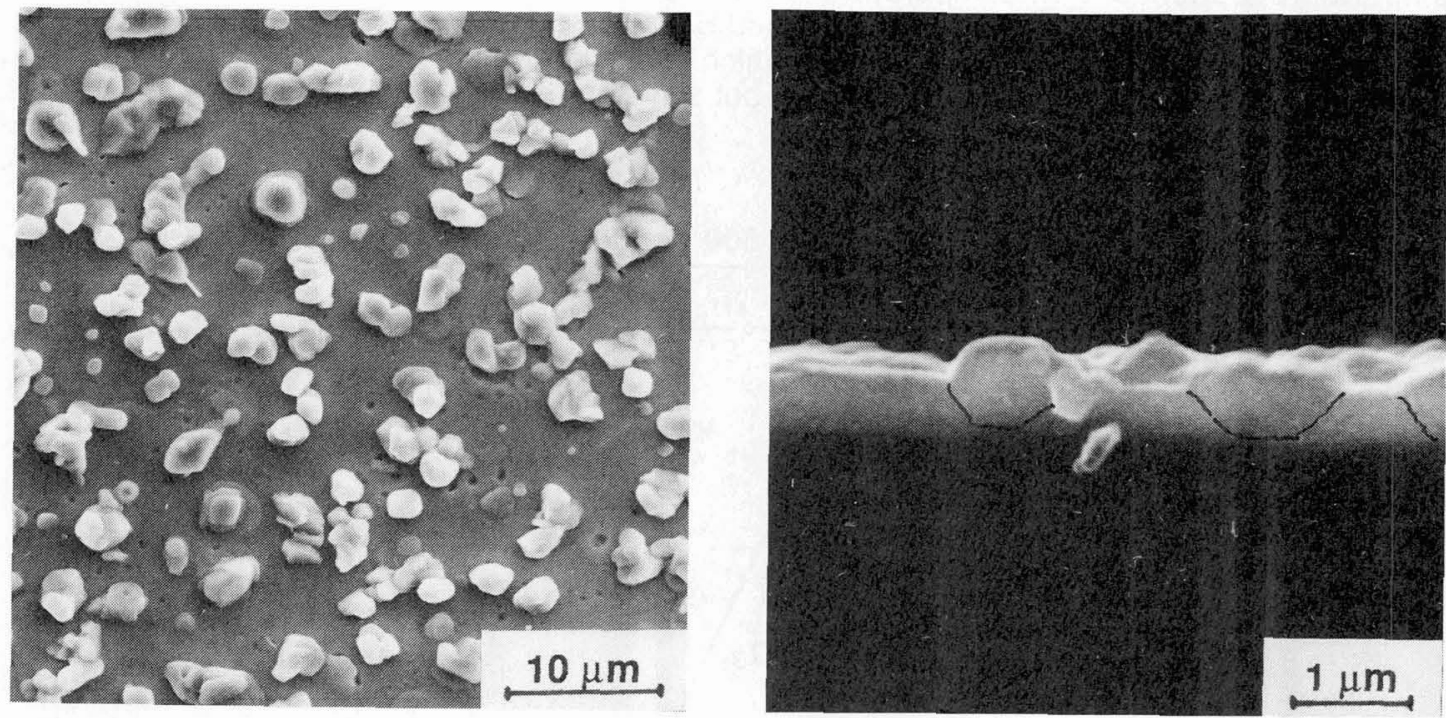

Fig. 5: SEM-picture of the surface morhology (a) and cross-section (b) of $\mathrm{YBa}_{2} \mathrm{Cu}_{3} \mathrm{O}_{7-\delta}$ on (100)-oriented $\mathrm{SrTiO}_{3}$-substrates

of $N_{t}$ with the composition of the 123-phase. With $\varepsilon$, the total composition of the layer is given by:

$$
\mathrm{Y}_{\alpha} \mathrm{Ba}_{\beta} \mathrm{Cu} \gamma=(1-\varepsilon)\left(\mathrm{Y}_{1 / 6} \mathrm{Ba} / 6 \mathrm{Cu}_{3 / 6} \mathrm{O}_{7-\delta}\right)+\varepsilon\left(\mathrm{Cu}_{1-z} \mathrm{Y}_{z} \mathrm{O}_{n}\right) \quad(\text { with } \alpha+\beta+\gamma=1)
$$

Therefore $\varepsilon$ can be considered to be a measure of the surface density of precipitates and consequently of the roughness of the surface $15 / 28 /$.

Fig. 6 shows the $\mathrm{X}$-ray pattern of a typical $\mathrm{YBa}_{2} \mathrm{Cu}_{3} \mathrm{O}_{7-\delta}-\mathrm{coating}$ with an $\varepsilon$ of 0.05 . The diagram shows a strong (OOI)-orientation with the $c$-axis of the $\mathrm{YBa}_{2} \mathrm{Cu}_{3} \mathrm{O}_{7-\delta}$-unit cell perpendicular to the substrate surface. The maximum intensities are in the range of $10^{6} \mathrm{cps}$. In addition the rocking curve, which is a measure for the degree of orientation, was obtained by measuring $\theta$ of the (007)-plane. It shows a FWHM (= full width at half maximum) of $0.35^{\circ}$ which is comparable to coatings prepared by physical vapour deposition technologies /29/. The oxygen content in the coating, which was determined by calculating the length of the c-axis using the $d$-value of $(2 \theta-\theta)$ of the (007)-reflex $/ 30 /$, is between $6,9-7$. Coatings with such a strong c-axis orientation show a temperature-resistance behaviour as indicated in fig. 7 . The resistance decreases linearly with temperature, the transition temperature is in the range of $T_{c}$ $=90 \mathrm{~K}$. The critical current densities $\mathrm{j}_{\mathrm{c}}$ of the coatings in zero field were usually measured in liquid nitrogen at $77.3 \mathrm{~K}$, or in gaseous helium, if magnetic fields were applied. Before measuring, the samples had to be patterned by wet chemical etching in $\mathrm{H}_{3} \mathrm{PO}_{4}$ in order to reduce the absolute current and therefore the heat stress on the contacts. The widths of the current bridges were between 25 and $100 \mu \mathrm{m}$. The current and voltage contacts were made by sputtering $\mathrm{Au}$ pads onto the superconductor and connecting $\mathrm{Ag}$ wires with the help of $\mathrm{Ag}$ paste or metallic indium, which was pressed onto the Au pads. The critical current densities $j_{c}$ of the measured samples, having layer thicknesses between 1 and $2 \mu \mathrm{m}$ and $\varepsilon<0.4$, show jc values in the range of $10^{6} \mathrm{~A} / \mathrm{cm}^{2}$ at $77 \mathrm{~K}$ in self magnetic field. A systematic dependence of $\mathrm{jc}_{\mathrm{c}}$ on $\varepsilon$ could not be found within the investigated range $(\varepsilon<0.4)$. 


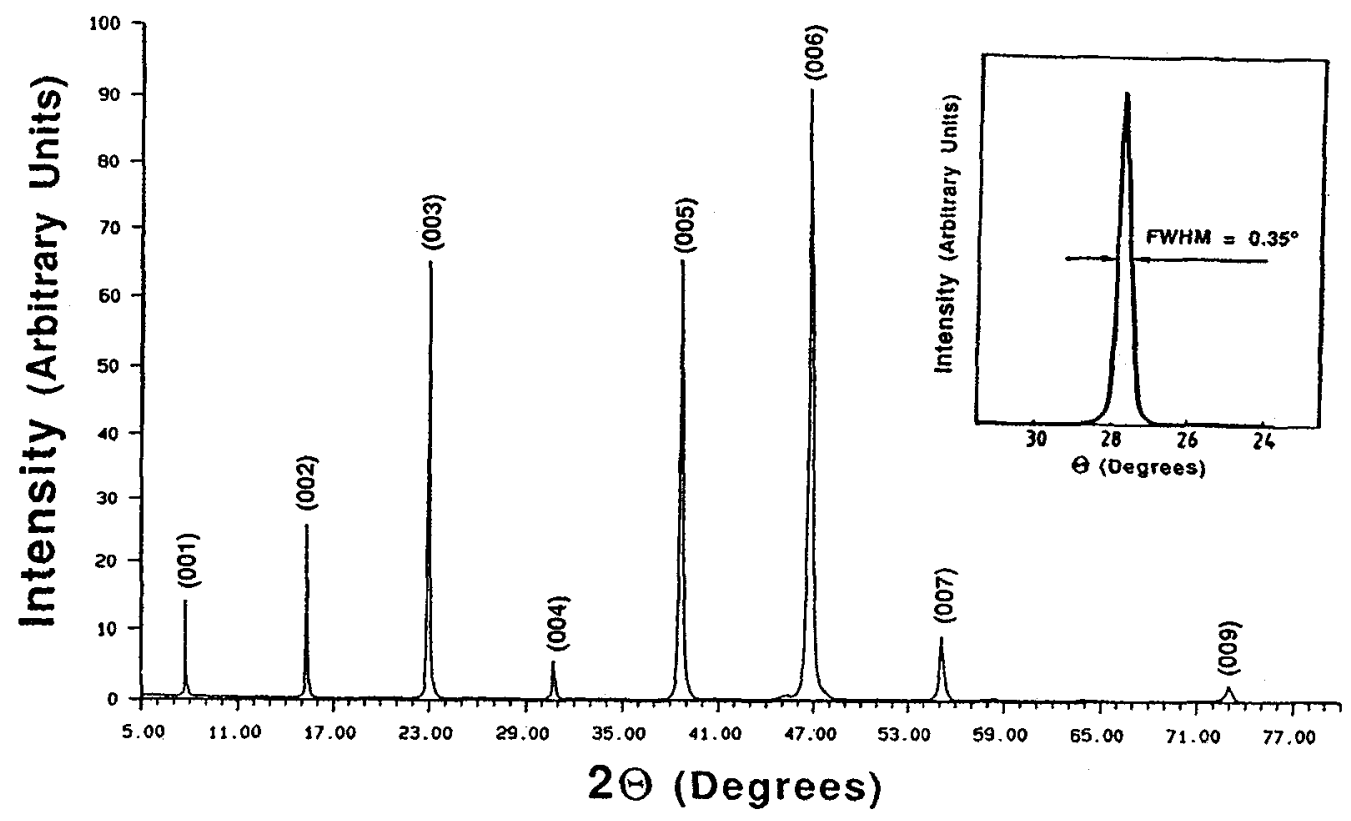

Fig. 6: X-ray pattern of $\mathrm{YBa}_{2} \mathrm{Cu}_{3} \mathrm{O}_{7-\delta}$ on (100)-oriented $\mathrm{SrTiO}_{3}$ and rocking curve

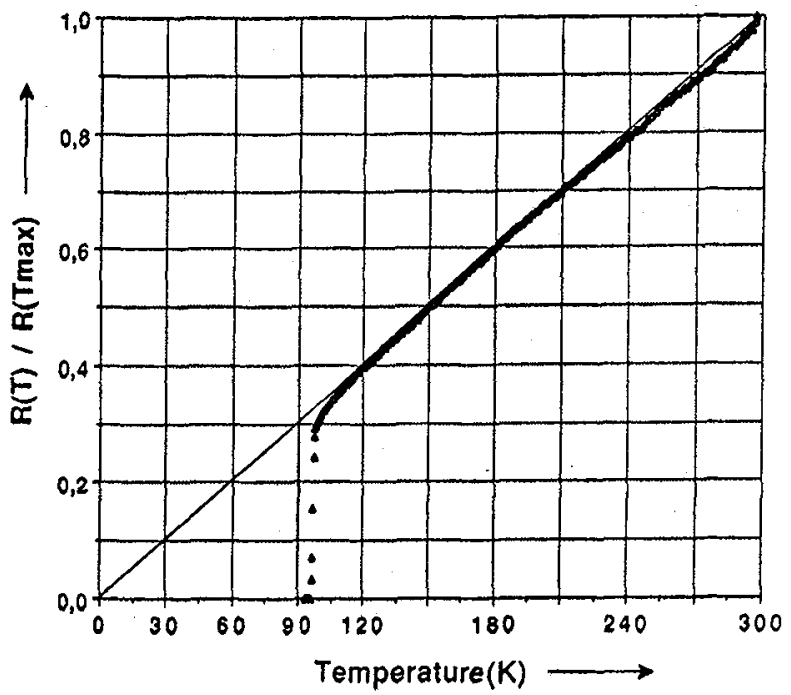

Fig. 7: Temperature-resistance behaviour of $\mathrm{YBa}_{2} \mathrm{Cu}_{3} \mathrm{O}_{7-\delta}$ on (100)-oriented $\mathrm{SrTiO}_{3}$

\section{Conclusion:}

Chemical vapour deposition is a suitable method to deposit High-T $\mathrm{C}^{-}$-superconductors with good properties $\left(T_{C}>90 \mathrm{~K}, j_{c}(0 T, 77)>10^{6} \mathrm{~A} / \mathrm{cm}^{2}\right)$ also on coatings having layer thicknesses larger than $1 \mu \mathrm{m}$. The most critical point till now is the quality of the precursors which often results in fluctuations of the evaporation rates and therefore in coatings with varrying amounts of non-superconductive precipates which reduce the superconducting cross-section. 


\section{Literature}

11/ M.L. Hitchman, D.D. Gilliland, D.J. Cole-Hamilton, S.C. Thompson; Inst. Phys. Conf. Ser. No 111, (1990) 305

12/ R.K. Mehrotra, R.C. Mehrotra; Metal-diketonates and allied derivatives. Academic Press, London, 1978

13/ R.E. Sievers, J.W. Connolly, W.D. Ross; J. Gas Chromatogr. 5 (1967) 241

14/ M. Ottosson, A. Harsta, J.O. Carlsson; Proc. XI. Int. CVD-Conf.; ed. by K.E. Spear, G.W. Cullen, 1990, ECS, Pennington, p. 180

15/ F. Schmaderer, Thesis, Universität Karlsruhe, 1990

/6/ F. Schmaderer, R. Huber, H. Oetzmann and G. Wahl; Appl. Surf. Sci. 46 (1990) 53-60

II E. Fitzer, H. Oetzmann, F. Schmaderer, G. Wahl; this proceedings.

18/ I. Barin, $O$. Knacke, O. Kubaschewski, Thermodynamic properties of inorganic substances; Supplement, Springer Verlag, 1977

19/ A.J. Panson, R.G. Charles, D.N. Schmidt, J.R. Szedon, G.J. Machiko,

A.I. Braginski; Appl. Phys. Lett. 53 (1988) 1756

$110 /$ S. Shibata, K. Sone, Bl. chem. Soc. Japan 29 (1956) 852

111 Z.A. Zarikowa, E.A. Shugam, Z. Struktur. Chim. 10 (2) (1969) 290

112 W.H. Watson, W.W. Holey; Croat. Chem. Acta 57 (1984) 467

113/ S. Shibata, K. lijima, T. Inuzuka; J. of Molecular Structure, 144 (1986) 181

114/ F.J. Hollander, D.H. Templeton, A.Zalkin, Acta Crystallogr. B29 (1973)

115/ P.H. Dickinson, T.H. Geballe, A.Sanjurjo, D. Hildenbrand, G. Craig,

M. Zisk, J. Collmann, S.A. Banning and R.E. Sievers; J. Appl. Phys. 66 (19089) 444

$116 /$ S. Matsumo, F. Uchikawa and K. Yoshizaki; 2nd Jap. J. of Appl. Phys. 29 (1990) 947

117 C.F. Barron; STREM-Chemiker, Vol. XIII, 1990

118/ Netherlands Organisation for Applied Scientific Research TNO, European Patent Appl. No. 90201485.1

/19/ H. Oetzmann, U. Vogt and F. Schmaderer; unpublished results

/20/ Z.M. Zhang, R.W. Wessels, D.S. Richardson, T.M. Marks, D.C. DeGroot, C.R. Kannenwurf; J.Appl. Phys., to be published.

121/ S. Heck, Th. Kruck, A. Lutz, J. Schmickler, C. Terfloth; Proc. III German-Soviet Bilateral Seminar on High-Temperature Superconductivity, Karlsruhe, 1990

122/ B. Schulte, W. Becker, E.G. Schlosser, S. Elschner, M. Maul, P. Häussler, H. Adrian; submitted to Appl. Phys. Lett.

/23/ M. Inoue, E. Takese, Y. Takai, H. Hayakawa; Nagoya University, Japan

124/ W.J. Lackey, W.B. Carter, J.A. Hanigofsky, D.N. Hill, E.K. Barefield, G. Neumeier, D.F. O'Brien, M.J. Shapiro, J. R. Thompson, A.J. Green, T. S. Moss; Appl. Phys. Lett. 56 (12), 1990

125/ F. Schmaderer and G. Wahl, J. Phys. C5 (1989) 119

126/ F. Schmaderer, R. Huber, H. Oetzmann and G. Wahl, Proc. ICMC '90 Topical Conf. on HTSC, Materials Aspects, May 9-11, 1990, Garmisch-Partenkirchen, to be published

127/ F. Schmaderer, R. Huber, H. Oetzmann, G. Wahl. Proc. XI CVD Conf. 1990, ed by K.E. Speer, G.W. Cullen, ECS, Pennington 1990 p. 211

128/ F. Schmaderer, R. Huber, H. Oetzmann, G. Wahl, Metall, 44 Jg., 1990, 638

129/ Q. Li, O. Meyer, X.X. Xi, J. Geerk, G. Linker; Appl. Phys. Lett. 55 (17) 1989, 1792

130/ R.J. Cava, B. Battlog, C.H. Chen, E.A. Riethman, S.M. Zahurak, D. Werder; Nature 329, 423 (1987) 5719 